\title{
Acaricidal activity of juazeiro leaf extract against red spider mite in cotton plants
}

\author{
José Cláudio Barros Ferraz ${ }^{(1)}$, Cláudia Helena Cysneiros Matos(1), Carlos Romero Ferreira de Oliveira(1), \\ Maria das Graças Rosa de Sá(1) and Antônia Gilciléia Cunha da Conceição(1)
}

\begin{abstract}
(1)Universidade Federal Rural de Pernambuco, Unidade Acadêmica de Serra Talhada, Avenida Gregório Ferraz Nogueira, s/no, José Tomé de Souza Ramos, CEP 56909-535 Serra Talhada, PE, Brazil. E-mail: claudioagronomia@gmail.com, ccysne@hotmail.com, crfoliveira@hotmail.com, mariarosa.eags@hotmail.com, gilcileia.cunha@gmail.com
\end{abstract}

\begin{abstract}
The objective of this work was to evaluate the toxicity, repellency, efficiency, and phytotoxicity of the aqueous extract of juazeiro (Ziziphus joazeiro) leaves in the control of the red spider mite, Tetranychus ludeni, on cotton plant. For toxicity evaluation, T. ludeni adult females were put on cotton leaf discs sprayed with the juazeiro extract. The repellent effect was verified in arenas that contained cotton leaf discs treated or not with the aqueous extract. The control efficiency of the juazeiro extract was evaluated by the infestation of cotton plants by adult female mites, followed by spraying with the extract. Measured $\mathrm{LC}_{50}$ was $3.54 \%(\mathrm{~m} / \mathrm{v})$, with $76.47 \%$ mortality and repellent effect. There was control efficiency for 120 hours, with $78.02 \%$ average, without significant difference between the evaluation intervals. Cotton plants did not show phytotoxicity. The juazeiro aqueous extract shows potential as an alternative control of $T$. ludeni on cotton plant due to its high toxicity, repellent effect, and efficiency in causing mortality, without being phytotoxic to cotton plants.
\end{abstract}

Index terms: Gossypium hirsutum, Tetranychus ludeni, Ziziphus joazeiro, mortality, plant extract, toxicity.

\section{Extrato de folhas de juazeiro com atividade acaricida sobre o ácaro-vermelho em algodoeiro}

Resumo - O objetivo deste trabalho foi avaliar a toxicidade, a repelência, a eficiência e a fitotoxicidade do extrato aquoso de folhas de juazeiro (Ziziphus joazeiro) no controle do ácaro-vermelho, Tetranychus ludeni, em algodoeiro. Para a avaliação da toxicidade, colocaram-se fêmeas adultas de T. ludeni sobre discos foliares de algodoeiro pulverizados com extrato de juazeiro. $\mathrm{O}$ efeito repelente foi verificado em arenas que continham discos de folha de algodoeiro tratados ou não com o extrato aquoso. A eficiência de controle do extrato de juazeiro foi avaliada pela infestação de plantas de algodoeiro com fêmeas adultas do ácaro, seguida de pulverização com o extrato. A $\mathrm{CL}_{50}$ determinada foi de $3,54 \%(\mathrm{~m} / \mathrm{v})$, com mortalidade de $76,47 \%$ e efeito repelente. Houve eficiência de controle por 120 horas, com média de 78,02\%, sem diferença significativa entre os intervalos de avaliação. As plantas de algodão não apresentaram fitotoxicidade. $\mathrm{O}$ extrato aquoso de juazeiro apresenta potencial como controle alternativo de T. ludeni em algodoeiro, em virtude de sua elevada toxicidade, efeito repelente e eficiência quanto à mortalidade, sem ser fitotóxico ao algodoeiro.

Termos para indexação: Gossypium hirsutum, Tetranychus ludeni, Ziziphus joazeiro, mortalidade, extrato vegetal, toxicidade.

\section{Introduction}

The action of insect pests is one of the main factors affecting cotton productivity and profitability in Northeastern Brazil, hindering the expression of the yield potential of cultivars (Beltrão \& Azevedo, 2008).

The cotton plant (Gossypium hirsutum L.) is host to numerous pests - present in its different phenological stages -, of which the bean red spider mite, Tetranychus ludeni (Zacher, 1913) (Acari: Tetranychidae), stands out (Moraes \& Flechtmam, 2008).
Mites are controlled by synthetic acaricides that are efficient but may cause environmental pollution, leave high residues in food, and cause biological imbalance, by eliminating natural enemies and causing the emergence of resistant mite and tick populations (Vieira et al, 2006; Pontes et al., 2007; Barrêto et al., 2010).

Therefore, there is a growing interest in alternative pest control practices in agroecosystems, in order to reduce the use of synthetic insecticides/acaricides (Lucini et al., 2010; Azevedo et al., 2013). An alternative to synthetic acaricides is using natural 
secondary metabolites extracted from plants, which show promising results in the control of phytophagous mites (Barrêto et al., 2010; Marangoni et al., 2012).

Plant products with acaricide activity may cause the following effects: repellency; inhibition of mite feeding, oviposition, and growth; alterations in morphogenetic, hormonal, and sexual behavior; sterilization in adults; and mortality in the immature or adult stage, among others (Dequech et al., 2008).

Among the botanical acaricide sources, the juazeiro (Ziziphus joazeiro Martius) (Rhamnaceae) stands out due to its efficiency in negatively affecting the physiology and behavior of pests from the Tetranychidae family (Siqueira et al., 2014; Xavier et al., 2015). Despite the advantages of botanical acaricides, studies conducted to date pointed out several limitations to the use of these products against T. ludeni, such as the lack of subsidies related to pest control efficiency, and the residual effects and phytotoxicity of the acaricide in cotton plants (Esteves Filho et al., 2013).

Due to the importance of botanical insecticides and to the few reports on the control of $T$. ludeni, there is a need to test an alternative control strategy that can be incorporated into the integrated management of cotton pests.

The objective of this work was to evaluate the toxicity, repellency, efficiency, and phytotoxicity of the aqueous extract of juazeiro (Ziziphus joazeiro) leaves in the control of the red spider mite, T. ludeni, on cotton plant.

\section{Materials and Methods}

The experiments were carried out in the experimental area of the academic unit of Serra Talhada of Universidade Federal Rural de Pernambuco, in the state of Pernambuco, Brazil, from October 2014 to May 2015. The cotton seeds for the experiments were provided by Embrapa Algodão.

To prepare the extracts, juazeiro leaves were collected in January and February 2015, in late afternoon, when the plants were in the flowering and fruiting stages. After being collected, leaves were disinfected in $0.05 \%$ active chlorine solution for 20 min (Vieira et al., 2006). Subsequently, the leaves were washed in distilled water; oven-dried at $45^{\circ} \mathrm{C}$ for 48 hours until constant weight; then grinded in a grinder and weighed. Extract concentrations $(\mathrm{m} / \mathrm{v})$ were 0, 1.5,
3.0, 4.5, 6.0, and 7.5\% dry leaf mass for each $100 \mathrm{~mL}$ distilled water. The material was refrigerated at $8 \pm 2{ }^{\circ} \mathrm{C}$ for 24 hours until the crude extract was obtained. Plant materials are deposited in Herbário do Semiárido do Brasil (Hesbra, voucher \#391).

'BRS 201' cotton plants were grown and maintained in a wooden cage $(1.0 \times 1.0 \times 1.0 \mathrm{~m})$, coated with voile type fabric to prevent natural infestation by insects and mites. Plants were grown individually in polyethylene pots with $5.0 \mathrm{~kg}$ capacity, containing a 3:1:1 ratio of soil, Plantmax commercial substrate (a compound with expanded vermiculite and plant organic materials that is insect-, disease-, and weed-free), and bovine manure. Plants were irrigated as needed.

Mites were grown in Gerbox plates containing arenas with jack bean [Canavalia ensiformis (L.) DC.] (Fabaceae) leaves placed with their upper sides facing down on a 4-cm thick foam layer, constantly moistened with distilled water. Leaf edges were covered with hydrophilic cotton to prevent mites from migrating to the other side of the leaf. Leaves were replaced by newer ones as needed, and mites were transferred to the new arena with a brush or by placing the older leaf on the new arena, allowing the mites to go from one leaf to the other. The mite populations were kept in BOD climatic chambers, at $25 \pm 2^{\circ} \mathrm{C}, 70 \pm 10 \%$ relative humidity (RH), and 12-hour photophase.

Juazeiro extract toxicity on $T$. ludeni adult females was evaluated using 60-day-old 'BRS 201' cotton leaf discs, with $3 \mathrm{~cm}$ in diameter, which were washed with distilled water and dried at room temperature $\left(27 \pm 2^{\circ} \mathrm{C}\right)$. The discs were then transferred individually to Petri dishes containing $1 \mathrm{~cm}$-thick foam covered with filter paper, surrounded by hydrophilic cotton moistened with distilled water to maintain humidity. Ten adult T. ludeni females were placed on each disc. Then, a hand sprayer was used to spray $2 \mathrm{~mL}$ (approximately $0.28 \mathrm{~mL} \mathrm{~cm}^{-2}$ ) of juazeiro leaf aqueous extract at the concentrations $(\mathrm{m} / \mathrm{v})$ of $0,1.5,3.0,4.5,6.0$, and $7.5 \%$. The arenas were kept in a climatic chamber at $25 \pm 2^{\circ} \mathrm{C}$, $70 \pm 5 \% \mathrm{RH}$, and 12-hour photophase (Matos et al., 2009). Living and dead individuals were counted 48 hours post-spraying. The completely randomized design was used, with six treatments and ten replicates. The resulted were subjected to the analysis of variance (Anova), and means were compared by Tukey's test, at $5 \%$ probability, using the Sisvar software (Ferreira, 2011). The corrected mortality 
(Mc) was calculated using Abbott's formula (1925): $\mathrm{Mc}=\{[(\mathrm{Mo}-\mathrm{Mt}) /(100-\mathrm{Mt})]\} \times 100$, in which Mc is the corrected mortality, in function of the control treatment; Mo is the observed mortality after the treatment with the extract; and Mt is the mortality observed in the control treatment. The toxicological effects of the aqueous extracts of juazeiro leaves on $T$. ludeni were grouped according to Hassan et al. (1994), considering the percentages of corrected mortality, as: innocuous, $<25 \%$; slightly toxic, $25-50 \%$; moderately toxic, $51-75 \%$; and highly toxic, $>75 \%$.

The median lethal concentration $\left(\mathrm{LC}_{50}\right)$ for the $T$. ludeni adult female population tested was calculated from the average mortality data - in the $(\mathrm{m} / \mathrm{v}) 0,1.5$, 3.0, 4.5, 6.0, and 7.5\% concentrations of the toxicity test - subjected to the Probit analysis in the StatPlus 2009 Professional software (AnalystSoft Inc., Walnut, CA, USA).

Sixty-day-old 'BRS 201' cotton leaf discs, with $3 \mathrm{~cm}$ in diameter, were also used to determine the repellency effect of $\mathrm{LC}_{50}$ juazeiro extracts on T. ludeni. The experiment was conducted in arenas containing two leaf discs, immersed for $5 \mathrm{~s}$ in the extract, then dried for $30 \mathrm{~min}$ at room temperature $\left(27 \pm 2^{\circ} \mathrm{C}\right)$. One disc was treated with the aqueous extract in the obtained $\mathrm{LC}_{50}$ (treatment), and the other with distilled water (control). Then, the discs were placed in Gerbox plates, containing 1-cm thick foam covered with filter paper, surrounded by hydrophilic cotton moistened with distilled water. Discs were connected with a coverslip $(18 \times 18 \mathrm{~mm})$, on which ten female adult mites were released, according to the methodology of Esteves Filho et al. (2010), with modifications. After 48 hours, the number of live mites on each disc was counted. The repellency index (RI) was calculated using the equation: $R I=2 G /(G+P)$, in which $G$ is the percentage of mites attracted to the treatment and $\mathrm{P}$ is the percentage of mites attracted to the control. The RI values varied between zero and two, in which $\mathrm{RI}=1$ indicates that the treatment and the control showed similar repellency (neutral treatment), RI $>1$ indicates that the treatment was less repellent than the control (attractive treatment); and RI $<1$ indicates that the treatment was more repellent than the control (repellent treatment). To classify the aqueous extract as repellent or not, the safety interval obtained from the average RI and the respective standard deviation (SD) was used, i.e., the extract was repellent if the mean RI value was less than (1 - SD), attractive if RI was greater than $1+\mathrm{SD}$, and neutral if $\mathrm{RI}$ was between $(1-\mathrm{SD})$ and $(1+\mathrm{SD})$. These indices are an adaptation of the equation described by Kogan \& Goeden (1970) for the consumption index.

The control efficiency at $\mathrm{LC}_{50}$ and phytotoxicity of the juazeiro leaf extract on adult $T$. ludeni females were observed on 'BRS 201' cotton plants grown and kept in a wooden cage $(0.5 \times 0.5 \times 1.0 \mathrm{~m})$ coated with voile type fabric. Plants were grown individually in polyethylene pots, with $5.0 \mathrm{~kg}$ capacity, containing a 3:1:1 ratio of soil, Plantmax commercial substrate, and bovine manure. Irrigation was performed as needed. The completely randomized design was used, with three replicates of two treatments: $\mathrm{T} 1$, three plants sprayed with juazeiro extract; and T2, control treatment, with three plants sprayed with distilled water. At 60 days post-emergence, plants were infested with 30 adult $T$. ludeni females. After 12 days of infestation, the juazeiro extract at the $\mathrm{LC}_{50}$ determined in the laboratory was sprayed on the undersides of the leaves. Spraying was done until leaf surfaces were fully covered, but not dripping. A commercial 5 -L backpack sprayer was used. The same procedure was adopted when distilled water was sprayed on the control. After 48, 72, 96, and 120 hours postspraying, two pre-determined leaves were collected from the lower, middle, and top thirds of each cotton plant, totaling six leaves per plant. Tetranychus ludeni female adults were counted with the aid of a $9-\mathrm{cm}^{2}$ magnifying eyepiece. With these results, the agronomic efficiency (E) was calculated using an adaptation of Abbott's (1925) equation: $E(\%)=[(t-p) /(t \times 100)]$, in which $t$ is the infestation in the control and $p$ is the infestation in the treatment. Mortality results were subjected to the Anova, and means were compared by Tukey's test, at $5 \%$ probability, with the Sisvar software (Ferreira, 2011). Phytotoxic effects were evaluated 48, 72, 96, and 120 hours after the application of the juazeiro extract, and scores were assigned according to symptom intensity, following the adapted scale proposed by Martins et al. (2004). The percentage of total leaf area with symptoms was obtained by evaluating the leaves of each plant, using the following grading scale: 0 , leaf area without symptoms; 1 , between 1 and $20 \%$ of leaf area with symptoms; 2, between 21 and 40\%; 3, between 41 and $60 \%$; 4, between 61 and $80 \%$; and 5 , over $81 \%$. 


\section{Results and Discussion}

The average mortality percentage of $T$. ludeni females treated with juazeiro extract ranged from 17 to $81 \%$. The highest concentration used differed statistically from the two lowest ones. There were no significant differences in the extract concentrations from 4.5 to $7.5 \%(\mathrm{~m} / \mathrm{v})$ (Table 1). However, when corrected mortality was considered, these concentrations were grouped in the moderately to highly toxic clusters, respectively. In the concentrations of 4.5 to $7.5 \%$, an average mortality between 60 and $81 \%$ was observed for the mite population; however, since there were no significant differences among the evaluated concentrations, the most promising one was $3.0 \%$, because it caused a $50 \%$ mortality rate.

The acaricide potential of juazeiro leaves on tetranychid mites was also verified by Siqueira et al. (2014), who found repellency and toxicity of different juazeiro extract concentrations against Mononychellus tanajoa Bondar (Acari: Tetranychidae) adult females. The juazeiro aqueous extract also shows potential for the alternative control of the red spider mite, T. bastosi Tuttle, Baker \& Sales (1997), in physic nut (Jatropha curcas L.), causing a high mortality rate of female mites (Xavier et al., 2015).

Under laboratory conditions, the effect of different plant extracts on phytophagous mite mortality has been reported. Aqueous extracts of garlic (Allium cepa L.) and agave (Agave angustifolia Haw.) reduce T. urticae (Koch, 1836) (Acari: Tetranychidae) survival, causing a mortality rate higher than $83 \%$ (Veronez et al., 2012). Acaricidal effects on T. urticae females were found for the aqueous extracts of Mentha spicata $\mathrm{x}$ suaveolens (Lamiaceae), Mentha piperita
L. (Lamiaceae), and Laurus nobilis L. (Lauraceae), as well for the hydroalcoholic extracts of Corymbia citriodora (Hook.) K.D. Hill \& L.A.S. Johnson (Syn. Eucalyptus citriodora Hook) (Myrtaceae), M. piperita, Cissus sicyoides L. (Vitaceae), and Calendula officinalis L. (Asteraceae) (Vieira et al., 2006). Residual effect tests showed that the extracts of Annona squamosa L., Calendula officinalis L., Coffea arabica L., Ricinus communis L. Ginkgo biloba L., and Nepeta cataria L. were promising, leading to over $60 \%$ mortality in Oligonychus ilicis (McGregor, 1917) (Acari: Tetranychidae) mites (Carvalho et al., 2008).

The biological activity of plant extracts can be attributed to several compounds that, independently or together, may contribute to acaricidal activity (Yanar et al., 2011). Juazeiro extract toxicity is associated with the action of secondary compounds present in leaves, such as saponins (Gusman et al., 2008; Siqueira et al., 2014). These substances, known as allelochemicals, are water-soluble and can be naturally released for defense against herbivory; their toxicity is related to their ability to form steroid complexes, interfering in the absorption of these compounds or disrupting cell membranes, which hinders insect growth and development (Taiz \& Zeiger, 2006; Oliveira et al., 2009; Marangoni et al., 2012).

The $\mathrm{LC}_{50}$ value of the juazeiro extract on T. ludeni was $3.54 \%(\mathrm{~m} / \mathrm{v})$, considered very low, given that aqueous extracts usually require higher concentrations to cause pest death (Siqueira et al., 2014; Maciel et al., 2015; Xavier et al., 2015). The values for $\mathrm{LC}_{90}=8.81 \%$ $(\mathrm{m} / \mathrm{v})$ and $\mathrm{LC}_{100}=9.71 \%(\mathrm{~m} / \mathrm{v})$ were also estimated.

$\mathrm{LC}_{50}$ was repellent and highly toxic to adult female mites, according to the toxicological cluster (Table 2). The repellent effect of plant extracts is considered

Table 1. Toxicity of the aqueous extract of juazeiro (Ziziphus joazeiro) leaves on adult females of the red spider mite, Tetranychus ludeni, infesting 'BRS 201' cotton (Gossypium hirsutum), as well as toxicological cluster ${ }^{(1)}$.

\begin{tabular}{lcccc}
\hline Aqueous extract (\%) & Dead individuals & Average mortality (\%) & Corrected mortality (\%) & Toxicological cluster $^{(2)}$ \\
\hline 0.0 & $1.70 \pm 0.50 \mathrm{c}$ & 17 & - & - \\
1.5 & $2.50 \pm 0.44 \mathrm{c}$ & 25 & 9.64 & Innocuous \\
3.0 & $5.20 \pm 0.44 \mathrm{~b}$ & 52 & 42.17 & Slightly toxic \\
4.5 & $6.00 \pm 0.42 \mathrm{ba}$ & 60 & 51.81 & Moderately toxic \\
6.0 & $7.30 \pm 0.44 \mathrm{ba}$ & 73 & 67.47 & Moderately toxic \\
7.5 & $8.10 \pm 0.43 \mathrm{a}$ & 81 & 77.11 & Highly toxic \\
\hline
\end{tabular}

${ }^{(1)}$ Means followed by equal letters, in the columns, do not differ by Tukey's test, at $5 \%$ probability. ${ }^{(2)}$ Innocuous, $<25 \%$ mortality; slightly toxic, $25-50 \%$; moderately toxic, $51-75 \%$; and highly toxic, $>75 \%$. Temperature, $25 \pm 2{ }^{\circ} \mathrm{C}$; relative humidity, $70 \pm 5 \%$; and photophase, 12 hours. 
an efficient way to prevent insect-pest infestation in agricultural areas and is an important feature for any bioinsecticide (Andrade et al., 2013; Xavier et al., 2015).

Other studies have also reported repellency of plant extracts against different pests. Juazeiro extracts repelled female T. bastosi mites on physic nut (Xavier et al., 2015) and the green mite, M. tanajoa, on cassava (Manihot esculenta Crantz) (Siqueira et al., 2014). This indicates that bioactive substances in juazeiro interfere with the behavior of these mites. In juazeiro, saponins and caffeine have been described as the main secondary compounds present in the leaves (Gusman et al., 2008; Siqueira et al., 2014; Xavier et al., 2015). Other compounds, such as omealoic acid, botulinic acid, starch, vitamin C, mineral salts, and proteins, have also been isolated (Lima, 1989). However, there is still a need to identify all bioactive substances that have an effect on T. ludeni and determine their concentrations in juazeiro aqueous leaf extracts.

The juazeiro extract was effective in controlling female $T$. ludeni mites in all evaluation times, which did not differ significantly from each other (Figure 1). Moreover, the extract did not cause phytotoxicity symptoms on 'BRS 201' cotton 120 hours after application, scoring 0 on the evaluation scale, indicating absence of symptoms on leaves.

The efficiency of plant extracts for the control of mites is considered satisfactory when mortality rates are higher than $60 \%$ and excellent when they exceed $80 \%$ (Potenza et al., 2006). Therefore, the juazeiro extract was satisfactory in T. ludeni control, with an

Table 2. Repellent effect of the aqueous extract of juazeiro (Ziziphus joazeiro) leaves at the median lethal concentration $\left(\mathrm{LC}_{50}\right)$ on adult females of the red spider mite, Tetranychus ludeni, infesting 'BRS 201' cotton (Gossypium hirsutum), as well as toxicological cluster.

\begin{tabular}{lc}
\hline Aqueous extract & Effect \\
\hline $\mathrm{LC}_{50}$ concentration $(\mathrm{m} / \mathrm{v})^{(1)}$ & $3.54 \%$ \\
Toxicological cluster & Highly toxic \\
Repellency index \pm standard deviation & $0.3267 \pm 0.6305$ \\
Classification & Repellent \\
\hline
\end{tabular}

${ }^{(1)} \mathrm{m} / \mathrm{v}$, mass/volume. ${ }^{(2)}$ The toxicological effects of the juazeiro extract on mites were clustered according to the model of Hassan et al. (1994), as: innocuous, $<25 \%$ mortality; slightly toxic, $25-50 \%$; moderately toxic, $51-75 \%$; and highly toxic, $>75 \%$. Temperature, $25 \pm 2{ }^{\circ} \mathrm{C}$; relative humidity, $70 \pm 5 \%$; and photophase, 12 hours. average control efficiency of $78.02 \%$ over 120 hours. This shows that, if used correctly, this botanical acaricide should be extremely efficient in the integrated management of this insect pest.

Natural products contain compounds that degrade more rapidly than most synthetic chemicals, signifying a decrease in the chance of pest arthropods developing resistance, minor residual effects, and low toxicity to humans (Hincapié et al., 2008; Veronez et al., 2012). In addition, aqueous extracts can have lower persistence than other types of extracts (Venzon et al., 2008; Marangoni et al., 2012; Veronez et al., 2012), explaining the results observed in the present study. Light is one of the major causes of pesticide degradation after application in the environment; this degradation depends on exposure duration, light wave intensity and length, temperature, humidity, and pesticide chemical composition (Yu, 2008).

The results presented here indicate that the aqueous extract of juazeiro leaves is highly toxic to the mite T. ludeni, besides repelling and causing mortality of adult females for up to 120 hours, without being phytotoxic to cotton. Therefore, juazeiro extract is promising to be used in the integrated management of this mite, especially in organic and in family cotton farming.

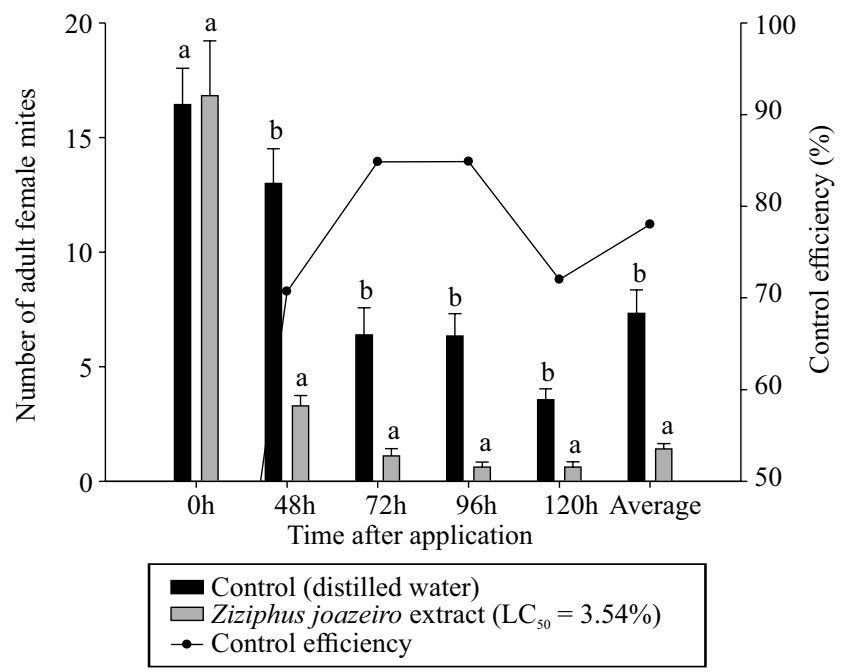

Figure 1. Count of adult females of the red spider mite, Tetranychus ludeni, infesting 'BRS 201' cotton (Gossypium hirsutum) leaves, treated with the aqueous extract of juazeiro (Ziziphus joazeiro) leaves, as well control efficiency of the median lethal concentration $\left(\mathrm{LC}_{50}\right)(3.54 \%)$, in a semi-field experiment. 


\section{Conclusion}

The aqueous extract of juazeiro (Ziziphus joazeiro) leaves is highly toxic to the red spider mite, Tetranychus ludeni; has repellent effect and is efficient in causing the mortality of adult females up to 120 hours post-spraying at a low $\mathrm{LC}_{50}$; and is not phytotoxic to cotton.

\section{Acknowledgments}

To Coordenação de Aperfeiçoamento de Pessoal de Nível Superior (Capes), for the scholarship granted.

\section{References}

ABBOTT, W.S. A method of computing the effectiveness of an insecticide. Journal of Economic Entomology, v.18, p.265-267, 1925. DOI: $10.1093 /$ jee/18.2.265a.

ANDRADE, L.H. de; OLIVEIRA, J.V. de; LIMA, I.M. de M.; SANTANA, M.F. de; BREDA, M.O. Efeito repelente de azadiractina e óleos essenciais sobre Aphis gossypii Glover (Hemiptera: Aphididae) em algodoeiro. Revista Ciência Agronômica, v.44, p.628-634, 2013. DOI: 10.1590/S180666902013000300027.

AZEVEDO, F.R.; SANTOS, C.A.M. dos; NERE, D.R.; MOURA, E.S.; GURGEL, L.S. Inseticidas vegetais no controle de Anastrepha spp. (Diptera: Tephritidae) em pomar de goiaba. Holos, v.4, p.77-86, 2013. DOI: 10.15628/holos.2013.1362.

BARRÊTO, A.F.; ARAÚJO, E.; BONIFÁCIO, B.F. Eficiência de extratos de Agave sisalana (Perrine) sobre o ácaro rajado Tetranychus urticae (Koch) e ocorrência de fitotoxidez em plantas de algodoeiro (Gossypium hirsutum L. r latifolium Hutch). Revista Brasileira de Agroecologia, v.5, p.207-215, 2010.

BELTRÃO, N.E. de M.; AZEVEDO, D.M.P. de. (Ed.). O agronegócio do algodão no Brasil. 2.ed. rev. e ampl. Brasília: Embrapa Informação Tecnológica, 2008. 2v.

CARVALHO, T.M.B. de; REIS, P.R.; OLIVEIRA, D.F. de; CARVALHO, G.A.; CARVALHO, D.A. de. Avaliação de extratos vegetais no controle de Oligonychus ilicis (McGregor, 1917) (Acari: Tetranychidae) em laboratório. Coffee Science, v.3, p.94103, 2008.

DEQUECH, S.T.B.; RIBEIRO, L. do P.; SAUSEN, C.D.; EGEWARTH, R.; KRUSE, N.D. Fitotoxicidade causada por inseticidas botânicos em feijão-de-vagem (Phaseolus vulgaris L.) cultivado em estufa plástica. Revista da FZVA, v.15, p.71-80, 2008.

ESTEVES FILHO, A.B.; OLIVEIRA, J.V. de; MATOS, C.H.C. Eficiência residual de acaricidas sintéticos e produtos naturais para Tetranychus urticae Koch, em algodoeiro. Revista Brasileira de Ciências Agrárias, v.8, p.583-588, 2013. DOI: 10.5039/agraria. v8i4a3073.

ESTEVES FILHO, A.B.; OLIVEIRA, J.V.; TORRES, J.B.; GONDIM JR, M.G.C. Biologia comparada e comportamento de
Tetranychus urticae Koch (Acari: Tetranychidae) e Phytoseiulus macropilis (Banks) (Acari: Phytoseiidae) em algodoeiro Bollgard $^{\mathrm{TM}}$ e isolinha não-transgênica. Neotropical Entomology, v.39, p.338-344, 2010. DOI: 10.1590/S1519-566X2010000300005.

FERREIRA, D.F. Sisvar: a computer statistical analysis system. Ciência e Agrotecnologia, v.35, p.1039-1042, 2011. DOI: 10.1590/ S1413-70542011000600001.

GUSMAN, G.S.; BITTENCOURT, A.H.C.; VESTENA, S. Alelopatia de Baccharis dracunculifolia DC. sobre a germinação e desenvolvimento de espécies cultivadas. Acta Scientiarum. Biological Sciences, v.30, p.119-125, 2008. DOI: 10.4025/ actascibiolsci.v30i2.3592.

HASSAN, S.A.; BIGLER, F.; BOGENSCHÜTZ, H.; BOLLER, E.; BRUN, J.; CALIS, J.N.M.; COREMANS-PELSENEER, J.; DUSO, C.; GROVE, A.; HEIMBACH, U.; HELYER, N.; HOKKANEN, H.; LEWIS, G.B.; MANSOUR, F.; MORETH, L.; POLGAR, L.; SAMSOE-PETERSEN, L.; SAUPHANOR, B.; STÄUBLI, A.; STERK, G.; VAINIO, A.; VAN DE VEIRE, M.; VIGGIANI, G.; VOGT, H. Results of the sixth joint pesticide testing programme of the iobc/wprs-working group: pesticides and beneficial organisms. Entomophaga, v.39, p.107-119, 1994. DOI: $10.1007 /$ BF02373500.

HINCAPIÉ, C.A.; LÓPEZ, G.E.; TORRES CH., R. Comparison and characterization of garlic (Allium sativum L.) bulbs extracts and their effect on mortality and repellency of Tetranychus urticae Koch (Acari: Tetranychidae). Chilean Journal of Agricultural Research, v.68, p.317-327, 2008. DOI: 10.4067/ S0718-58392008000400001.

KOGAN, M.; GOEDEN, R.D. The host-plant range of Lema trilineata daturaphila (Coleoptera: Chrysomelidae). Annals of the Entomological Society of America, v.63, p.1175-1180, 1970. DOI: 10.1093/aesa/63.4.1175.

LIMA, D.A. Plantas da Caatinga. Rio de Janeiro: A Tribuna dos Santos, 1989. 243p.

LUCINI, T.; SCABENI, C.; DEDORDI, C.; HIROSE, E.; SHIOMI, H.F. Efeito de extrato aquoso de Capsicum baccatum na mortalidade e oviposição de Tetranychus ludeni (Acari: Tetranychidae). Scientia Agraria, v.11, p.355-358, 2010.

MACIEL, A.G.S.; RODRIGUES, J.S.; TRINDADE, R.C.P.; SILVA, E.S.; SANT'ANA, A.E.G.; LEMOS, E.E.P. Effect of Annona muricata L. (1753) (Annonaceae) seeds extracts on Tetranychus urticae (Koch, 1836) (Acari: Tetranychidae). African Journal of Agricultural Research, v.10, p.4370-4375, 2015. DOI: 10.5897/AJAR2015.10201.

MARANGONI, C.; MOURA, N.F. de; GARCIA, F.R.M. Utilização de óleos essenciais e extratos de plantas no controle de insetos. Revista de Ciências Ambientais, v.6, p.95-112, 2012.

MARTINS, M.C.; GUERZONI, R.A.; CÂMARA, G.M. de S.; MATTIAZZI, P.; LOURENÇO, S.A.; AMORIM, L. Escala diagramática para a quantificação do complexo de doenças foliares de final de ciclo em soja. Fitopatologia Brasileira, v.29, p.119-184, 2004. DOI: 10.1590/s0100-41582004000200009.

MATOS, C.H.C.; PALLINI, A.; VENZON, M.; FREITAS, R.C.P. de; REZENDE, D.D.M.; SCHOEREDER, J.H. Os tricomas de Capsicum spp. interferem nos aspectos biológicos 
do ácaro-branco, Polyphagotarsonemus latus Banks (Acari: Tarsonemidae)? Neotropical Entomology, v.38, p.589-594, 2009. DOI: 10.1590/S1519-566X2009000500005.

MORAES, G.J. de; FLECHTMANN, C.H.W. Manual de acarologia: acarologia básica e ácaros de plantas cultivadas no Brasil. Ribeirão Preto: Holos, 2008. 306p.

OLIVEIRA, A.K. de; DIÓGENES, F.É.P.; COELHO, M. de F.B.; MAIA, S.S.S. Alelopatia em extratos de frutos de juazeiro(Ziziphus joazeiro Mart. - Rhamnaceae). Acta Botanica Brasilica, v.23, p.1186-1189, 2009. DOI: 10.1590/S0102-33062009000400029.

PONTES, W.J.T.; OLIVEIRA, J.C.S. de; CÂMARA, C.A.G. da; GONDIM JUNIOR, M.G.C.; OLIVEIRA, J.V. de; SCHWARTZ, M.O.E. Atividade acaricida dos óleos essenciais de folhas e frutos de Xylopia sericea sobre o ácaro rajado (Tetranychus urticae Koch). Química Nova, v.30, p.838-841, 2007. DOI: 10.1590/ S0100-40422007000400015.

POTENZA, M.R.; GOMES, R.C.O.; JOCYS, T.; TAKEMATSU, A.P.; RAMOS, A.C.O. Avaliação de produtos naturais para o controle de ácaro rajado Tetranychus urticae (Koch, 1836) (Acari: Tetranychidae) em casa de vegetação. Arquivos do Instituto Biológico, v.73, p.455-459, 2006.

SIQUEIRA, F.F. da S.; OLIVEIRA, J.V. de; FERRAZ, C.S.; OLIVEIRA, C.R.F. de; MATOS, C.H.C. Atividade acaricida de extratos aquosos de plantas de Caatinga sobre o ácaro verde da mandioca. Revista Caatinga, v.27, p.109-116, 2014.

TAIZ, L.; ZEIGER, E. Fisiologia vegetal. 3.ed. São Paulo: Artmed, 2006.
VENZON, M.; ROSADO, M.C.; MOLINA-RUGAMA, A.J.; DUARTE, V.S.; DIAS, R.; PALLINI, A. Acaricidal efficacy of neem against Polyphagotarsonemus latus (Banks) (Acari: Tarsonemidae). Crop Protection, v.27, p.869-872, 2008. DOI: 10.1016/j.cropro.2007.10.001.

VERONEZ, B.; SATO, M.E.; NICASTRO, R.L. Toxicidade de compostos sintéticos e naturais sobre Tetranychus urticae e o predador Phytoseiulus macropilis. Pesquisa Agropecuária Brasileira, v.47, p.511-518, 2012. DOI: 10.1590/S0100204X2012000400006.

VIEIRA, M.R.; SACRAMENTO, L.V.S.; FURLAN, L.O.; FIGUEIRA, J.C.; ROCHA, A.B.O. Efeito acaricida de extratos vegetais sobre fêmeas de Tetranychus urticae Koch (Acari: Tetranychidae). Revista Brasileira de Plantas Medicinais, v.8, p.210-217, 2006.

XAVIER, M.V.A.; MATOS, C.H.C.; OLIVEIRA, C.R.F.; SÁ, M.G.R.; SAMPAIO, G.R.M. Toxicidade e repelência de extratos de plantas da Caatinga sobre Tetranychus bastosi Tutler, Baker \& Sales (Acari: Tetranychidae) em pinhão-manso. Revista Brasileira de Plantas Medicinais, v.17, p.790-797, 2015. DOI: 10.1590/1983-084X/14_063.

YANAR, D.; KADIOGLU, I.; GÖKÇE, A. Acaricidal effects of different plant parts extracts on two-spotted spider mite (Tetranychus urticae Koch). African Journal of Biotechnology, v.10, p.11745-11750, 2011.

YU, S.J. The toxicology and biochemistry of insecticides. Boca Raton: CRC Press, 2008. 276p.

Received on April 18, 2016 and accepted on July 28, 2016 